Case Law Analysis 



\title{
European Restrictions on the Application of National Provisions Concerning Access to Documents in Cases With a European Dimension
}

\author{
Ton P.W. Duijkersloot
}

University lecturer and researcher in Constitutional and Administrative Law at the Institute for Constitutional and Administrative Law of Utrecht University

\begin{abstract}
This study focuses on the implications of the landmark Tierschütz judgment of the European Court of Justice on the possibilities for Member States to rely on national rules on access to documents. In particular, it is concerned with the question of whether there is room for Member States to invoke exceptions to disclosure provided for by national law in cases when a document originating from that Member State is in the possession of a European institution and that institution is requested to provide the document. As far as national exceptions are concerned that have no equivalent in Regulation 1049/2001 this door seems to be closed by the ECJ decision in Tierschütz, however, there may still be some leeway. This analysis deals with this possibility and discusses questions and problems that result from it.
\end{abstract}

\section{Introduction}

Regulation I049/200I on access to documents has been the subject of various ECJ cases. ${ }^{\mathrm{I}}$ Most cases deal with the explanation of the exceptions on access, provided in the Regulation. From a European administrative law perspective these cases are interesting, but their relevance is limited. The Tierschütz case differs in that respect. ${ }^{2}$ This case touches on the possibility Member States have to rely on national laws on access to documents - esp. exceptions provided by the national laws - in cases with a European dimension. More specifically, it addresses the question of how Article 4(5) of Regulation I049/200I should be interpreted. According to this article a Member State may request the institution not to disclose a document originating from that Member State without its prior agreement. What does this provision mean? Does it attribute to the Member States a veto-right as far as documents originating from a Member State and being in the possession of an EU institution are concerned? Might that veto be inspired not only by exceptions provided in Regulation I049/200I, but also by exceptions provided in national law? Or is its meaning much more restricted and

I Cf. D. Adamski, 'How wide is “the widest possible”? Judicial interpretation of the exceptions to the right of access to official documents revisited', CMLRev. (46) 2009, p. 52I-549.

2 Court of Justice i8 December 2007, Case C-64/05P. 
does it only provide for some kind of opinion given by that Member State on whether an exception in Regulation I049/200I is applicable?

Besides these important questions concerning the possibilities to invoke national law and national exceptions, the Tierschütz judgment also raises questions about judicial protection. This contribution contains an analysis of the Tierschütz case and pays attention to these questions. It also takes into account a recent judgment of the General Court (the former Court of First Instance), Co-Frutta, that elaborates on the earlier Tierschütz judgment. ${ }^{3}$

\section{The Tierschütz Case}

\section{I Facts}

IFAW Internationaler Tierschütz-Fonds GmbH (TF), a non-governmental organisation active in the field of protecting animal welfare and the conservation of nature, exchanged correspondence with the Commission with to the intention of being granted access to certain documents. These documents related to a project concerning the Mühlenberger Loch site which consisted of the enlargement of the Daimler Chrysler Aerospace Airbus $\mathrm{GmbH}$ factory and the reclamation of part of the estuary for a runway extension. The correspondence was exchanged in accordance with the rules on access to documents laid down in Commission Decision 94/90 on public access to Commission documents which was in force at the time. In the course of that correspondence, the Commission gave certain documents to TF. Then TF requested access to a series of additional documents pursuant to Regulation I049/200I, including documents originating from the German authorities. The Commission informed the applicant that, because of Article 4(5) of Regulation I049/200I, the Commission was obliged to receive an agreement from the German authorities before disclosing any documents received from them. TF replied that it did not accept that interpretation of Article 4(5) of the Regulation. It stated that the German authorities may request the Commission not to disclose a document originating in that Member State without its prior agreement, but the final decision concerning disclosure remains with the Commission and must be based upon one of the exceptions in Article 4 of Regulation I049/200I where there is no overriding public interest in the disclosure. Then the Federal Republic of Germany asked the Commission not to disclose the requested correspondence. Consequently the Commission informed TF that the documents originating from the German authorities could not be made available to it.

3 General Court i9 January 2010, Joined Cases T-355/04 and 446/04. 


\subsection{Background: The CFI Wrongly Introducing a Veto-Right}

In an earlier judgment, the Messina case in 2003, the Court of First Instance (CFI) had already concluded that Article 4(5) attributed to the Member States a right of veto. ${ }^{4}$ Although this judgment was concerned with an unusual exercise of a Member State's right of veto, because of the fact that this veto was issued after the Commission had already taken the decision not to provide access to the requested information, in this Messina judgment the CFI already made clear that it interpreted 'right of veto' in Article 4(5) of Regulation I049/200I to mean 'without prior agreement'.

This line of thought was elaborated on by the CFI in Tierschütz. Before the CFI, TF submitted, in essence, that whilst the Member State from which a document originates may request the institution in possession of that document not to disclose it under Article 4(5) of the Regulation, it does not have a right of veto with respect to such disclosure, as the final decision is a matter for the institution. The CFI was (again) clear on this point: the argument by TF was based on a misinterpretation of the provisions of the Regulation and could not be upheld. The CFI started off by stating that the right of access to documents of the institutions provided for in Article 2 of the Regulation covers all documents held by the European Parliament, the Council and the Commission, that is to say, documents drawn up or received by them and in their possession within the meaning of Article 2(3). Accordingly, the institutions may be required, in appropriate cases, to make available documents originating from third parties, including, in particular, the Member States, in accordance with the definition of 'third party' in Article 3(b) of the Regulation.

Then the CFI stressed the changing of the former authorship rule by Regulation I049/200I. According to this authorship rule, that was part of the old regime on access under i.a. Commission Decision 94/90, the request had to be sent directly to the author. European institutions were only authorised to grant access to documents drawn up by these institutions. They were not authorised to disclose documents originating from a wide category of third parties, including the Member States. The person requesting access was obliged, where necessary, to make his request directly to the third party (the author) in question. ${ }^{5}$

Consequently the CFI explained the meaning of Article 4(4) concerning 'normal' third party documents. Article 4(4) of the Regulation places the institutions under an obligation to consult the third party concerned with a view to assessing whether an exception in Article 4(I) or (2) is applicable, unless it is clear that the document should or should not be disclosed. The CFI considered that it follows that the institutions are under no obligation

4 Court of First Instance i7 September 2003, Case T-76/02. Annotated by M.E. de Leeuw in CMLRev. 2004, p. 26I-280.

5 Cf. recital Io of Regulation I049/200I. 
to consult the third party concerned when it is apparent that the document should (or should not) be disclosed. In all other cases, the institutions must consult the relevant third party. Accordingly, in cases in which the duty to disclose documents is not apparent, consulting the third party is, as a general rule, a precondition for determining whether the exceptions to the right of access provided for in Article 4(I) and (2) of the Regulation are applicable in the case of third-party documents. However, the Commission's duty to consult third parties under Article 4(4) of the Regulation does not affect its power to decide whether one of the exceptions provided for in Article 4(I) and (2) of the Regulation is applicable.

The CFI then pointed out that the situation concerning Member State documents is a different one. It added that Article 4(5) of the Regulation places the Member States in a different position from that of other parties and lays down a lex specialis to govern their position. Under that provision, the Member State has the power to request an institution not to disclose a document originating from it without its 'prior agreement'. The obligation imposed on the institution to obtain the Member State's prior agreement, which is clearly laid down in Article 4(5) of the Regulation, would risk becoming meaningless if the Commission were able to decide to disclose that document despite an explicit request not to do so from the Member State concerned. Thus, contrary to what TF had argued, a request made by a Member State under Article 4(5) does in the words of the CFI, 'constitute an instruction to the institution not to disclose the document in question'. This instruction can hardly be called anything other than a 'right of veto'. Moreover, according to the CFI there was not even a duty for the Member State to give reasons for this instruction.

\subsection{ECJ: Rejecting a Right of Veto; Can Grounds for Refusal also Be Based on National Law?}

As already stated earlier, the Court of Justice itself has more recently dealt with all these observations and completely set aside the Tierschütz judgment of the CFI.

Firstly, the Court considered that, where a Member State has made use of the option provided in Article 4(5) of Regulation I049/200I to request that a specific document originating from that State should not be disclosed without its prior agreement, disclosure of that document by the institution requires the prior agreement of that Member State to be obtained. An agreement is legally different from a mere opinion. The very wording of Article 4(5) of Regulation I049/200 precludes the provision being interpreted in a manner in which it would merely confer on a Member State the right to be consulted by the institution before the institution decides, possibly despite the opposition of the Member State in question, to allow access to the document concerned. The fact that Article 4(5) of Regulation I049/200I uses the 
words 'may request' simply emphasizes that that provision gives the Member State an option, and only the actual exercise of that option in a particular case has the effect of making the prior agreement of the Member State a necessary condition of the future disclosure of the document in question.

Secondly, with regard to the veto-issue, the Court held that it is clear from recital Io in the preamble to, and Article 2(3) of, Regulation I049/200I that all documents held by the institutions are within the scope of the Regulation, including those originating from the Member States, so that access to such documents is in principle governed by the provisions of the Regulation, including those which lay down substantive exceptions to the right of access. Thus, the exceptions set out in Article 4(I) to (3) of the Regulation must be interpreted and applied strictly. Those exceptions delimit the exercise of the power conferred by Article 4(5) on the Member State concerned, the latter being given, in that respect, nothing more than a power to take part in the Community decision. Seen in this way, the prior agreement of the Member State referred to in Article 4(5) resembles not a discretionary right of veto but a form of assent confirming that none of the grounds of exception under Article 4(I) to (3) are present. It follows that Article 4(5) of Regulation I049/200I cannot be interpreted as conferring on the Member State a general and unconditional right of veto, so that it could in a discretionary manner oppose the disclosure of documents originating from it and held by an institution, with the effect that access to such documents would cease to be governed by the provisions of that Regulation and would depend only on the provisions of national law.

Thirdly, this assent should be motivated. The Court considers that a Member State which, at the conclusion of dialogue with a Community institution concerning the possible application of the exceptions laid down in Article 4(I) to (3) of Regulation I049/200I, objects to disclosure of the document in question is obliged to state reasons for that objection with reference to those exceptions. The institution cannot accept a Member State's objection to disclosure of a document originating from that State if the objection gives no reasons at all or if the reasons are not put forward in terms of the exceptions listed in Article 4(I) to (3) of Regulation I049/200I. Where, despite an express request by the institution to the Member State to that effect, the Member State still fails to provide the institution with such reasons, the institution must, if it considers that none of those exceptions applies, give access to the document that has been requested.

In essence, this Tierschütz judgment makes very clear that as far as the Court of Justice is concerned Article 4(5) of Regulation I049/200I has a much more limited meaning than the CFI was suggesting. 


\section{Implications for National Law on Access to Documents}

\section{I Is There Room for National Exceptions: The Relevance of This Question}

According to the ECJ in Tierschütz Art. 4(5) of Regulation I049/200I attributes Member States with the right to give their opinion to the EU institution that possesses a document originating from that Member State, when a citizen makes a request for access to that document to the institution. This raises the important question of whether Member States should base this opinion upon the exceptions provided for by Regulation I049/200I or (also) upon exceptions provided for by their national laws. This question is of relevance because the exceptions provided for by Regulation I049/200I differ in many aspects at least partly from the exceptions provided for by national law, f.i. the Dutch law on access to documents, the Wet openbaarheid van bestuur (Wob). Before answering this question, we can illustrate these differences by comparing the absolute and relative exceptions provided for by this Dutch Wob with the absolute and relative exceptions provided for by Regulation I049/200I.

The first two absolute exceptions in Regulation I049/200I (public security and defense) are also absolute exceptions under the Dutch Wob (they can be arranged under Art. Io lid I sub b Wob: the security of the State). The third absolute exception in Regulation I049/200I (the interest of international relations) though, is according to the Dutch Wob (just) a relative exception, which means that the interest protected by this exception should be balanced against the interest of transparency. The same applies as far as the protection of financial, monetary and economic policy and the protection of privacy are concerned: Art. Io lid $2 \mathrm{sub} b$ and e of the Dutch Wob contain merely a relative and not an absolute exception on this point. Only specific personal data protected by the Dutch Law on the protection of personal data (Wet bescherming persoonsgegevens; Wbp) are part of an absolute exception (Art. ro lid I sub d Wob). ${ }^{6}$ In essence, some of the absolute exceptions in Regulation I049/200I, have (just) a relative character in the Dutch Wob. On the other hand some relative exceptions under Regulation I049/200I have an absolute character under the Wob: the commercial interest of a natural or legal person is an absolute exception under the Wob (Art. Io lid I sub c Wob) - as far as information is concerned that is shared with the authorities by way of confidentiality - and a relative one under Regulation I049/200I.

Then there are also exceptions that are only provided in one of these two regimes. The Wob does not contain, unlike Regulation I049/200I, a specific

6 This concerns data meant by Art. I6 Wbp. 
exception protecting court proceedings and legal advice. ${ }^{7}$ Art. Io lid 2 sub c Wob only provides a relative exception protecting the interest of investigation and prosecution of criminal behaviour. On the other hand only the Wob contains an exception on the precaution of the unreasonable favouring or damaging of natural or legal persons involved or third parties, and the absolute exception of the unity of the Crown. Finally one should pay attention to the exception concerning 'internal counseling'. The exception in Art. II Wob is more limited than the exception provided for by 4(3) of Regulation I049/200I. The first one only comprises personal policy opinions which are part of documents for internal counseling, the exception in Regulation I049/200I is concerned with documents for internal counseling as such. In essence, this brief overview makes it very clear that there are various differences between Dutch law governing access to documents and Regulation I049/200I.

This overview also implies that the question of whether a Member State might invoke national exceptions is of particular relevance in those cases in which a Member State is of the opinion that an exception provided for by national law is at stake that is not covered by the exceptions of Regulation I049/200I. An example might be a situation in which a Dutch administrative authority is of the opinion that giving the Commission access to a document originating from the Netherlands might jeopardize the unity of the Crown. As mentioned before, this is an absolute exception under the Wob (Art. Io lid I sub a Wob) but Regulation I049/200I does not provide it. Another example might be a case in which the Netherlands is of the opinion that giving access to such a document might lead to the unreasonable advantage of a third party involved (Art. Io lid 2 sub g Wob). At this point it should be mentioned that this issue is not only of relevance when national exceptions are provided which are not part of Regulation I049/200I but also in cases in which both legal systems provide similar exceptions. In those cases case law of national and European courts on the interpretation of those exceptions might differ. This might also result in a Member State preferring to invoke a national exception.

From the perspective of transparency, the ability for Member States to invoke additional national exceptions might be undesirable. From the perspective of guaranteeing national access laws and preventing the circumvention of those laws, this ability is important however. This leads to the question of whether Regulation I049/200I, as interpreted by the ECJ in Tierschütz, leaves room for invoking national exceptions.

7 Although legal advice might be exempted as being part of 'internal counseling' mentioned in Art. II Wob. 


\subsection{A Clear Answer in Tierschütz?}

At first glance a study of the Tierschütz judgment gives the impression that, according to the ECJ, Member States only are allowed to invoke the exceptions provided for by Regulation I049/200I itself. For instance, in consideration 67 the Court considers:

'(..) it is clear from recital 10 in the preamble to and Article 2(3) of Regulation $1049 / 2001$ that all documents held by the institutions are within the scope of the regulation, including those originating from the Member States, so that access to such documents is in principle governed by the provisions of the regulation, including those which lay down substantive exceptions to the right of access.'

In consideration 76 the Court continues by holding:

'several factors militate in favour of an interpretation of Article 4(5) to the effect that the exercise of the power conferred by that provision on the Member State concerned is delimited by the substantive exceptions set out in Article 4(1) to (3), with the Member State merely being given in this respect a power to take part in the Community decision. Seen in that way, the prior agreement of the Member State referred to in Article 4(5) resembles not a discretionary right of veto but a form of assent confirming that none of the grounds of exception under Article 4(1) to (3) is present.'

This clarity becomes somewhat blurred though when reading the cryptic consideration 84. The Court seems to suggest the possibility that Member States may rely on national exceptions when giving their opinion towards the EU institution. The ECJ holds:

'in particular, there is nothing to exclude the possibility that compliance with certain rules of national law protecting a public or private interest, opposing disclosure of a document and relied on by the Member State for that purpose, could be regarded as an interest deserving of protection on the basis of the exceptions laid down by that regulation'.

In particular, this consideration raises the question of whether a Member State may rely on a national exception on access, for instance, whether the Netherlands might invoke the exception provided for by the Wob concerning the unity of the Crown. How should the Tierschütz judgment of the ECJ be interpreted? 


\subsection{The Proposal to Amend Regulation I049/200I and the Opinion of A-G Poiares Maduro}

The Commission's proposal to modify Regulation I049/200I points to the direction of a positive answer to the question of whether national exceptions can be invoked. ${ }^{8}$ In this proposal Tierschütz is codified by the Commission in a new Article 5(2) that reads as follows:

'Where an application concerns a document originating from a Member State, other than documents transmitted in the framework of procedures leading to a legislative act or a nonlegislative act of general application, the authorities of that Member State shall be consulted. The institution holding the document shall disclose it unless the Member State gives reasons for withholding it, based on the exceptions referred to in Article 4 or on specific provisions in its own legislation preventing disclosure of the document concerned.(..)'

The last sentence leads to the conclusion that a Member State, according to the Commission proposal, may base its opinion on both exceptions in Regulation I049/200I, and in national law. Also the opinion of A-G Poiares Maduro in Tierschütz pointed in this direction. He concluded:

'a Member State may not of course put forward any reason it wishes to oppose disclosure of the requested document by the institution to which the request for disclosure is directed. It follows from Article 255(2) EC that the reasons must necessarily relate to public or private interests. However, the reasons of 'public or private interest' the Member State may put forward are not limited to the exceptions to the right of access laid down by the Regulation; they may also be drawn from the national law of the Member State concerned.' 9

The acceptance of this view, however, raises various questions and problems. Ultimately, this favours the conclusion that this view is not correct, or at least not what the ECJ intended to say. I will discuss a few of those questions and problems in the coming paragraphs. Firstly, what are, or should be the consequences of a negative opinion of a Member State based on its own national law. Is there a duty for the EU institution to follow this opinion? Should the EU institution itself also weigh the various interests at stake? Secondly, on which grounds should the EU institution, in case it follows the opinion of the Member State, base its decision on access? Thirdly, what are the implications for judicial protection for an EU citizen in access cases about the access to Member States documents in the possession of an EU institution?

8 COM (2008) 229 fin.

9 Opinion A-G Poiares Maduro, point 50. 
3.4 Consequences of a Negative Opinion of Member State for the Decision of the Institution

A negative opinion of a Member State on giving access can be based on various grounds. First and foremost, in Tierschütz the ECJ made clear that the opinion should be stated with reasons. ${ }^{\text {o }}$ Where, despite an express request by the institution to the Member State to that effect, the Member State still fails to provide the institution with such reasons, the institution must, if it considers none of the exceptions apply, give access to the document that has been requested. If the Member State gives reasons and puts those forward in terms of the exceptions in Regulation I049/200I the institution is itself obliged to give reasons for a decision to refuse a request for access to a document. Such an obligation means that the institution must, in its decision, not merely record the fact that the Member State concerned has objected to disclosure of the document requested, but also set out the reasons relied on by that Member State to show that one of the exceptions to the right of access in Article 4(I) to (3) of the regulation applies. That information will allow the person who has asked for the document to understand the origin and grounds of the refusal of his request and the competent court to exercise, if need be, its power of review. ${ }^{\text {II }}$ Apart from that, at least in theory, it is also possible that the institution puts the opinion of the Member State aside and takes a decision contrary to the opinion of the Member State. In practice, however, this is unlikely to happen.

The most intriguing question is how an EU institution should deal with a negative opinion of a Member State that is founded upon national exceptions. Is it up to the institution to consider whether this reason is valid? For instance, is it up to the Commission to judge whether the Netherlands justifiably have invoked the exception of the unity of the Crown? The answer seems to be no. The Commission has the power to interpret and apply community law, but not national law. That is up to the Member States themselves. The Commission itself seems to share this view. The proposed new Article 5(2) holds that the institution shall appreciate the adequacy of reasons given by the Member State to the extent that they are based on exceptions laid down in this Regulation. The same will be true for cases in which the European Court should judge the lawfulness of a national exception put forward by a Member State. I will discuss this subject in more detail in par. 3.6.

\footnotetext{
I0 Tierschütz, point 88 .

II Tierschütz, point 89 .
} 


\subsection{Grounds for Refusal of Access: The Position of the EU Institution}

Another question is on what kind of exception the EU institution should base its refusal, in case a Member State has given a negative opinion based on a national exception. Quite logically, this has to be an exception in Regulation I049/200I. After all, that is the law the institution is obliged and competent to apply. This raises the problem that such an exception is not always available. If, for instance, the Netherlands relies on the exception of 'the unity of the Crown', it is difficult to find an exception in Regulation I049/200I that might be applicable.

It is interesting to take notice of the fact that under Dutch law (the Wob) such an exception is available for the opposite situation: if a Dutch authority possesses a European document, Art. Io(2) sub a Wob might serve as some kind of general exception. This exception deals with 'the interest of the relations of the Netherlands with other states and international organisations'. Case law of the highest Dutch administrative law court, the Council of State, has made clear that this exception might be used in case a request is made to a Dutch administrative authority for access to a European document. ${ }^{22}$ If the EU institution from which the document originated makes clear that it opposes giving access to this document - according to Art. 5 Regulation I049/200I in cases like this the Member State has to ask the EU institution for its opinion - Art. Io(2) sub a Wob can be used to transform this negative opinion by the institution into a national refusal. Regulation I049/200I, however, does not provide a similar exception. Art. 4(I) sub a, third indent, at first sight seems to be a provision that might contain such a possibility: according to this exception EU institutions shall refuse access to a document where disclosure would undermine the protection of the public interest as regards international relations. Unlike its Dutch counterpart this provision cannot serve as a 'safety net'. What is meant by 'international relations' in this article is relations between the EU and third countries. The internal relations between the EU and the Member States are outside the scope of this article. This is underlined by the fact that an exception that did include those internal relations was part of the original proposal for Regulation I049/200I and has been removed in the final version of the regulation. ${ }^{13}$

We therefore might draw the conclusion that the ECJ in Tierschütz intended to deny the possibility of putting forward national exceptions, unless these exceptions match exceptions in Regulation I049/200I. If the Commission takes a different opinion, which might be drawn from Art. 5(2) of the Commission proposal - it better should also introduce in the proposal an exception as was proposed in the original proposal for Regula-

\footnotetext{
I2 Council of State 23 November 2005, LJN AU6653 and Council of State 9 April 2008, LJN BC9089.

I3 Compare COM (2000) 0030 (def), Art. 4 sub a, third indent.
} 
tion I049/200I, thus implying that access can be refused in the interest of the relations between the EU and the Member States.

\subsection{Judicial Protection}

Another problem that occurs with the accepting of the possibility for Member States to invoke national exceptions, especially exceptions not included in Regulation I049/200 itself, is that of judicial protection. What kind of judicial protection is granted to an EU citizen if he has made a request to an EU institution for access to a document originating from a Member State that is refused due to a negative opinion from that Member State?

The answer is clear in case the Member State has founded its opinion upon the exceptions in Regulation I049/200I. Then one can lodge an appeal to the General Court and finally the Court of Justice against the refusal. As mentioned before, in Tierschütz the ECJ held explicitly that the institution not only records the fact that the Member State concerned has objected to disclosure of the document asked for, but also sets out the reasons relied on by that Member State to show that one of the exceptions to the right of access in Article 4(I) to (3) of the regulation applies. That information will allow the person who has asked for the document to understand the origin and grounds of the refusal of his request and the competent court to exercise, if need be, its power of review.

When a Member State relies on an exception according to national law, problems arise. I briefly mentioned before that there is very limited room for the ECJ to examine the legality of this opinion. The only aspect the ECJ might examine is whether the opinion of the Member State contains any motivation as such. If not, the institution would not be allowed to found its decision on this objection by the Member State and the refusal is unlawful. Is there room for the ECJ to examine the opinion of the Member State ex materiae? As far as the opinion is based on national law, the answer seems to be no. This is also the view of the ECJ itself, as expressed in Tierschütz. It holds:

'It is true that, according to settled case-law, in an action brought under Article 230 EC the Court has no jurisdiction to rule on the lawfulness of a measure adopted by a national authority'. ${ }^{14}$

In this respect it refers to the landmark Borelli case. ${ }^{15}$ In the Borelli judgment the ECJ also made clear however, that the principle of effective judicial protection implies that a binding advice from a Member State must be subject to judicial control. As the ECJ has no jurisdiction to rule on the

I4 Tierschütz, point 9I.

I5 ECJ 3 December 1992, Case C-97/91 (Borelli). 
national measure, any action would have to be brought at the national level. ${ }^{16}$ In other words, judicial control has to be provided, whether it be on the EU or national level.

What are the implications for the case at hand? One might argue that, at least in a formal way, the ECJ offers judicial protection: the ECJ is competent to examine the EU decision to refuse access. Whether this should be considered to be effective judicial protection ex materiae is a different question. In case the EU institution has founded its negative decision upon a negative opinion of a Member State, the ECJ cannot examine whether this recourse to the national exception is truly valid. This would then lead to a gap in judicial control.

This gap may be closed in two different ways. Firstly, in case the document also rests in the hands of the national authorities, a national request can be made and can be examined by a national court. Secondly, in line with Borelli, a national court could or should claim itself to be competent to examine the opinion of the Member State in case it is requested to do so. This raises interesting questions of procedural administrative law. In the Dutch situation the question will be whether this opinion should be qualified as a 'decision' in the meaning of Art. I:3 of the General Administrative Law Act (GALA). If the answer is affirmative then the Dutch administrative law court can examine the decision. If the answer were no, one could argue that Borelli should lead to a broad interpretation of the meaning of a decision under Dutch administrative law, including this opinion.

Another question is whether a citizen becomes aware of the opinion of the Member State. Will this opinion be made public? Should it be made public? Under Dutch law, if the opinion is qualified as a 'decision' it has to be made public according to Art. 3:4I of the GALA. This would imply that the citizen who has made the request for access to the EU institution has to be provided with the opinion of the Netherlands.

Concluding, as far as judicial protection is concerned, complications arise if we accept the interpretation of Tierschütz implying that national exceptions can be put forward, even if they do not match with the exceptions provided in Regulation I049/200I. As already mentioned before, this favours the conclusion that such a broad interpretation of Tierschütz might not be correct, at least might not be intended by the ECJ.

\subsection{The Recent Co-Frutta Judgment}

The General Court in its recent Co-Frutta judgment of I9 January 2010 also seems to share this view. ${ }^{17}$ In this case Co-Frutta company, an Italian undertaking engaged in the ripening of bananas, learned

${ }^{16}$ Cf. J.H. Jans, R. de Lange, S. Prechal en R.J.G.M. Widdershoven, Europeanisation of Public Law, Europa Law Publishing 2007, p. 246.

${ }^{17}$ See footnote 3 . 
through the Italian press, of allegedly fraudulent imports of bananas into the European Community between I998 and 2000 at a reduced tariff on the basis of false import licences. Co-Frutta considered itself affected by those imports because of serious price distortions caused by the placing of additional quantities on the Community market, leading the tariff quota to be exceeded, and claimed that the loss suffered would have been even greater if it transpired that the imports were made not with false licences, but with licences which had been properly issued, but on the basis of false or erroneous reference quantities, which would mean that its own reference quantity had been reduced. Co-Frutta therefore asked the Commission for access to certain documents concerning the Community rules governing the importation of bananas and a list of traditional operators registered during the years I998, I999 and 2000, specifying i.a the quantity of bananas imported by each operator during the period from I994 to I996, the provisional reference quantity attributed to each operator for the years 1998, 1999 and 2000 and the licences (quantities) issued to each operator during the years I998, I999 and 2000 and the corresponding use. These documents originated partly from the Italian authorities. These authorities opposed to the disclosure of these documents. As far as the interpretation of Tierschütz is concerned with regard to the aspect of invoking national exceptions the General Court holds in Co-Frutta the following:

'(..) the institution concerned cannot accept a Member State's objection to disclosure of a document originating from that State if the objection gives no reasons at all or if the reasons are not put forward in terms of the exceptions listed in Article 4(1) to (3) of Regulation No 1049/2001. Where, despite an express request to that effect by the institution concerned to the Member State, the Member State still fails to provide the institution with such reasons, the institution must, if for its part it considers that none of those exceptions applies, give access to the document that has been asked for. ${ }^{18}$

This makes clear that it is also the view of the General Court that the opinion of Member States with regard to the applicability of exceptions has to be stated in terms of exceptions of Regulation I049/200I. Of course, the Tierschütz judgment of this court has proved that the opinion of this court is not always upheld by the ECJ itself. Anyhow, the question remains what, in this view, is the meaning of the cryptic consideration 84 . Future case law of the ECJ may resolve this question.

I8 Co-Frutta, point 8I. 


\section{Conclusion}

The Tierschütz judgment is important because it makes clear that in certain cases Member States cannot prevent the disclosure on request of documents held by an EU institution which come from those Member States. They have the right to give their opinion stated with reasons, but this opinion is no veto-right. It seems that the reasons should also be put in terms of the exceptions mentioned in Regulation I049/200I. However, this last observation is somewhat debatable. Although the Tierschütz judgment itself points in this direction, one cryptic consideration (consideration 84) seems to leave room for putting forward national exceptions as well, those that have no counterpart in Regulation I049/200I in particular. Support for this possibility might also be drawn from the Commission proposal to modify Regulation I049/200I and the opinion of the Advocate-General. The acceptance of this view raises various questions. Some important ones, for instance, with regard to judicial protection, have been discussed in this case analysis. Because of those questions, it may be concluded that the ECJ in Tierschütz has intended to close this door. The General Court, in its recent Co-Frutta judgment, seems to share this opinion. The meaning of the cryptic consideration 84 in Tierschütz then, remains unclear. Anyhow, as a result of Tierschütz the role of national laws on access to documents and especially some typical national exceptions seems to have become restricted. 
